\title{
Interventionist Literary Histories: \\ Nostalgic, Pragmatic, or Utopian?
}

\author{
Linda Hutcheon
}

\begin{abstract}
$A^{\text {lthough literary-historical debates have been part of the history of }}$ Awestern literature from the start (as in the various European quarrels of ancients and moderns), literary history as we know it appears to have grown out of eighteenth-century antiquarian interests. In its earliest form it was often simply a compendium of information about writers (of practically anything), usually in straightforward chronological order. With Friedrich Schlegel, the story goes, came the shift from this sort of vast sequence of authors to a more limited corpus (and thus canon) of literary texts. ${ }^{1}$ The nineteenth century is generally viewed as the time of the greatest achievement in this vein, and many fundamental principles of Western literary history as a discipline were established then. ${ }^{2}$ It is no coincidence that the same moment in history also witnessed the rise of a new form of national cultural self-awareness.
\end{abstract}

${ }^{1}$ See Ernst Behler, "Problems of Origin in Modern Literary History," in Theoretical Issues in Literary History, ed. David Perkins (Cambridge, Mass.: Harvard University Press, 1991), 11-2.

2 See David Perkins, Is Literary History Possible? (Baltimore, Md.: Johns Hopkins University Press, 1992), 1-4, 86; and Hans Robert Jauss, "Literary History as a Challenge to Literary Theory," in Toward an Aesthetic of Reception, trans. Timothy Bahti (Minneapolis: University of Minnesota Press, 1982), 7-8. It may well be no accident that the physical conservation of historical artifacts also began in the late eighteenth and early nineteenth centuries; the rise of literary history may also (in this light) have been a sign of a "growing mystique of historical consciousness and an avid attachment to documents and physical traces of the past" (David Lowenthal, The Past Is a Foreign Country [Cambridge: Cambridge University Press, 1985], 393). Literary works may even be to literary history what relics are to history: signs of the tangible Modern Language Quarterly 59:4, December 1998. (C) 1998 University of Washington. 
The versions of the story of the past that the present tells have always been associated with questions of cultural authority and thus with politics, especially with some kind of "identity" politics. Since the nineteenth century the identity has been national, and so the accounts of the history of the nation's literature have played a significant role in the formation of certain national self-imaginings. ${ }^{3}$ Giving precedence to the German romantic articulation of the issues, many would argue that, precisely because the concept of the modern nation-state and the discipline of literary history were born together, they have been mutually implicated from the start, thanks both to the politics of cultural nationalism and to the rise of philology, which proved vital to the nineteenth-century sense of the specificity of languages and therefore of peoples and nations. ${ }^{4}$ While limited both historically and geographically, this romantic articulation has had a powerful effect on subsequent historical accounts of national literatures. ${ }^{5}$

past, open to being "found, resurrected, and deciphered," in danger of effacement and likely to change in meaning with new interpretations (239-41).

${ }^{3}$ While historians usually point to European countries, the United States followed the same pattern: "The urgency to invent an American nation and the urgency to invent a uniquely American literature were historically coincident" (Gregory S. Jay, American Literature and the Culture Wars [Ithaca, N.Y.: Cornell University Press, 1977], 177).

${ }^{4}$ There were, of course, other factors. The rise of the nation-state has been tied to the forms and subject matter of literature and other art forms. See Benedict Anderson, Imagined Communities: Reflections on the Origin and Spread of Nationalism, $2 \mathrm{~d}$ ed. (London: Verso, 1991); Timothy Brennan, "The National Longing for Form," in Nation and Narration, ed. Homi K. Bhabha (London: Routledge, 1990), 49; Herbert Lindenberger, Opera: The Extravagant Art (Ithaca, N.Y.: Cornell University Press, 1984), 257; Edward W. Said, Culture and Imperialism (New York: Knopf, 1993), 111-32; and Linda Hutcheon and Michael Hutcheon, "Otherhood Issues: PostNational Operatic Narratives," Narrative 3 (1995): 1-17.

${ }^{5}$ George Steiner even claims that "everywhere the history of modern literary studies shows the mark of this nationalist ideal of the mid-and late-nineteenth century" (Language and Silence: Essays, 1958-1966 [Harmondsworth: Penguin, 1969], 79).

Linda Hutcheon is University Professor of English and Comparative Literature at the University of Toronto. Her most recent books are Iromy's Edge: The Theory and Politics of Iromy (1994) and, with Michael Hutcheon, Opera: Desire, Disease, Death (1996). She is currently codirecting two comparative literary history projects on Latin America and eastern and central Europe. 
Today when we think of identity politics, however, we usually think of issues related to class, race, ethnicity, gender, sexuality, and a host of other categories with which people self-identify and which are not coincident with the boundaries of the nation-state. ${ }^{6}$ But the many new histories of the literatures written from these perspectives aim to confer cultural authority on the groups in question as surely as earlier national ones ever did. ${ }^{7}$ Like the historical narratives of nations, those of the newer forms of identity politics create a sense of continuity between past and present, usually with an eye to promoting ideological consensus. In the double function of granting authority and creating continuity lies the core of their shared political agendas-or, more accurately, their shared interventionist agendas.

Interestingly, the newer literary histories often adopt precisely the same developmental, teleological narrative model used earlier by nations. Yet obviously we live in a world very different in economic, social, and cultural terms from the one that saw the rise of the European or American nation-state. Our globalized fin de siècle world has created a complex and interrelated social context that is multiracial, multiethnic, and multicultural. Therefore there would seem to be no reason to expect such a model of national literary history to have remained appropriate: after all, it was built on single ethnicities and developed in a very different historical and philosophical frame of reference. As Homi K. Bhabha puts it: "The (relative) sovereignty of the nation-state and the assumed unity of national cultures, upon which such a perspective is based, are both fundamentally disturbed when the core areas turn into multivalent and ambivalent networks that project the periphery internally. Global migration acquires a new historical

${ }^{6}$ I realize that identity politics is a contested term, but I use it deliberately in response to precisely the current debates about its efficacy to draw an analogy between its literary-historical positioning and that of national identity politics.

${ }^{7}$ In 1970 , reacting to a perceived crisis in the field, the fledgling journal New Literary History devoted a special issue to the question "Is literary history obsolete?" By the late 1980 os literary history had been referred to as a "now almost moribund discipline" (Michael Sprinker, Imaginary Relations: Aesthetics and Ideology in the Theory of Historical Materialism [London: Verso, 1987], 3). But the last decade has witnessed a proliferation of new literary histories, not to mention the creation of an extensive body of both criticism and theory that has put historical issues at the very heart of cultural debates once again. Many of the new histories have been written from the perspective of marginalized groups. 
and theoretical importance in the post- or transnational context." These changes have come about, argues Bhabha, because the concept of the majority-ethnic nation-state has broken down.

Nevertheless, the earlier model of literary history stubbornly persists, not so much in the form of a simple explanatory or causal narrative (although it too continues) but, most obviously, in a teleological narrative of continual and organic evolution. Originally structured on the romantics' idealist philosophy of history, with its emphasis on the importance of origins and its assumption of continuous development, this model was intended to establish an implicit parallel between the inevitable progress of the nation and that of its literature. ${ }^{9}$ Hence its power and appeal. It enfolded the great (usually European) authors "within recurringly renewed structures, visions, stabilities, all of them attesting to the abiding dialectical order represented by Europe itself" (Said, 47)..$^{10}$

This kind of literary history has been seen as the totalizing verbal counterpart to the geographic world vision of empire visible on maps. Nevertheless, the decolonized nations of the postwar era have often

${ }^{8}$ Bhabha, "Editor's Introduction: Minority Maneuvers and Unsettled Negotiations," Critical Inquiry 23 (1997): $43^{6}$. Bhabha is discussing Etienne Balibar's article "Ambiguous Universality," differences 7 (1995): esp. 53-5.

9 "The new history of national literatures . . . became an ideal counterpart to political history, and claimed to develop, through the context of all literary phenomena, the idea of how national individuality could attain its identity, from quasimythical beginnings to the fulfillment of national classicism" (Jauss, $\mathbf{5}^{\mathbf{1}}$ ).

10 To borrow John Frow's strong formulation, marginalized groups demand a literary history that "understands that histories are fictions of power which can be rewritten, that the canon can be retrospectively changed or displaced . . that the opposition of the canonical to the noncanonical, which is constructed and maintained by the force of cultural and educational institutions, can be radically transformed" (Marxism and Literary History [Oxford: Blackwell, 1986], 122). On interventionism as an avowed characteristic of race or ethnic literary histories see Frederick Buell, National Culture and the New Global System (Baltimore, Md.: Johns Hopkins University Press, 1994), 162-3. For the feminist perspective see Marilyn L. Williamson, "Toward a Feminist Literary History," Signs 10 (1984): 137-8; Sandra Gilbert and Susan Gubar, "Tradition and the Female Talent," in Literary History: Theory and Practice, ed. Herbert L. Sussman, Proceedings of the Northeastern University Center for Literary Studies, 2 (Boston: Northeastern University, 1984), 20-1; and Donna Landry, "Figures of the Feminine: An Amazonian Revolution in Feminist Literary History?" in The Uses of Literary History, ed. Marshall Brown (Durham, N.C.: Duke University Press, 1995), 107. 
turned to it to legitimate their newly redefined identities. But so too have certain feminist, ethnic, African American, and gay, lesbian, or queer literary historians. Instead of lamenting their decision as retrograde, as some have done, I suggest that it is not the nostalgic move it at first appears to be. Rather, it may imply that the strategic power of identifying with an obviously successful national narrative of progress outweighs the danger of co-optation by a model that was, after all, often responsible for excluding the very groups these literary historians represent. Their decision may bear the marks of progressive utopian thinking, but it just as likely signals political pragmatism born of interventionist desire. This strategy, it would seem, has proved as successful in terms of the new politics of identity as it did when used by the nation-state in the nineteenth century.

That the writing of literary history serves political interests has often been masked by educational claims or by a rhetoric of scientific objectivity. Usually the political interests have been those of the nation-state, and in some postcolonial literary histories they still are. But what has become increasingly clear is that other forms of group identification also have a stake in how literature's history is told; marginalized groups, in particular, insist that it be told with an activist, interventionist dimension, which nation builders of the last two centuries have never forgotten, either. But what would this kind of "interventionary power" consist of for literary histories, which have been described, in tellingly paradoxical terms, as "among the most disregarded and influential of books"? 11 Of course, these often hefty volumes are rarely read cover to cover, but they are certainly consulted and often used to legitimate a particular historical narrative or "fiction of power" (Frow, 122).

Is there a narrative model that operates more effectively to this end than others? Interventionist political aims demand that pragmatic considerations not be ignored. Curiously, the most common form of narrative selected-the story of inevitable progress from traceable origins - is among the historical models whose underlying assumptions

11 Respectively, R. Radhakrishnan, "Nationalism, Gender, and the Narrative of Identity," in Nationalisms and Sexualities, ed. Andrew Parker et al. (New York: Routledge, 1992), 79; Marco A. Portales, "Literary History, a 'Usable Past,' and Space," Melus 11 (1984): 97 . 
have been challenged in recent years by theorists of historiography like Hayden White. ${ }^{12}$ But the timing of such challenges has been catastrophic for marginalized groups. Just as they are "entering history," the power and truth value of historical accounts are rendered unstable. ${ }^{13}$ This turn of events parallels another, much-remarked unfortunate coincidence-if it is one-between the challenges to the coherent subject (and its representation) and the very rise of identity politics. Bad timing may begin to explain the seeming unwillingness of some interventionist literary historians to surrender the traditional evolutionary model of literary history: in full awareness of its ideological limits (and indeed its serious dangers), they may still want to tell that once powerful story of progress for the record. ${ }^{14}$ It has been argued that the national narrative confers legitimacy and authority simply because it is a national model. More than perhaps any other form of collective life, the nation possesses immense imaginative power-so much power, in fact, that disenfranchised groups may feel the need to invoke it merely to validate their claims as political (see Parker et al., 8). Think of Queer Nation.

More important, teleological and developmental narratives suggest the progress that feminist and other interventionist agendas require, just as nineteenth-century European nationalist agendas required it. ${ }^{15}$ In other words, marginalized groups do not merely copy a recognized model because it has proved pragmatically effective. The

12 See White, Metahistory: The Historical Imagination in Nineteenth-Century Europe (Baltimore, Md.: Johns Hopkins University Press, 1973); and White, Tropics of Discourse: Essays in Cultural Criticism (Baltimore, Md.: Johns Hopkins University Press, 1978). See also Dominick LaCapra, History and Criticism (Ithaca, N.Y.: Cornell University Press, 1985 ).

${ }^{13}$ Janet Todd, Feminist Literary History: A Defence (Cambridge: Polity, 1988), 96.

14 The tension between these challenges and the demands of identity politics is expressed well by Henry Louis Gates Jr. when he writes of the simultaneous debunking of the stability of the "individual" and the move sometimes to "reconstitute and recuperate the same essential stability in the form of an ethnos that allegedly exhibits all the regularities and uniformities we could not locate in the individual subject" ("Beyond the Culture Wars: Identities in Dialogue," Profession 93 [1993]: 8).

15 Marshall Brown, arguing for the literary-historical power of the "not yet romantic," welcomes teleology for related reasons: its "looking ahead" and the "historical dynamic" inherent in "the process under way" (Preromanticism [Stanford, Calif.: Stanford University Press, 1991], 2, 3, 6). 
model itself appeals to the deeper need or desire to enact in literaryhistorical narrative the progress that their utopian and interventionist politics aims to deliver in history. After all, this model comes complete with evolutionary metaphors of organic growth. The narrative of the literature of the nation - like that of the nation itself - was and is usually written as one of natural and continual development (Perkins, 1-4).$^{16}$ In some feminist, ethnic, and postcolonial literary histories we still see today, in often radically adapted form, the persistent influence of the romantic historicist thinking of Johann Gottfried von Herder and others for whom the organicity and continuity of literature expressed the national spirit, the Volk (a term with unpleasant historical echoes today). ${ }^{17}$ Just as a national literature was seen to develop over time, increasing in quality, power, and authority, so too the nation itself would mature from its founding moment to its political apotheosis.

The potent combination of the nostalgic impact of origins (the founding moment) and linear utopian projection (into the future) that informs this narrative model is one clear reason for its consistent appeal to any group that has felt oppressed by dominant powers-on the level of nation but also of gender, sexual choice, class, race, ethnicity, language, or religion. Like nations, all marginalized groups "turn to the past in search of identity, tradition, and self-understanding. Their histories do not usually stress discontinuity but the opposite."18 In fact, literary histories not only create continuities but, in the process, confer legitimacy. That was the intent of the nationalist founders of the form in the past, and it is one of the aims of its interventionist practitioners today. ${ }^{19}$

${ }^{16}$ Interestingly, individual literary forms may be seen to be born, to flourish, and then to decline, but aesthetic degeneration is in constant tension with the national (and national literary) model of political evolution and progress.

${ }^{17}$ See René Wellek, Concepts of Criticism, ed. Stephen G. Nichols Jr. (New Haven, Conn.: Yale University Press, 1963), 333.

18 David Perkins, "Introduction: The State of the Discussion," in Perkins, Theoretical Issues, 4 .

${ }^{19}$ Interestingly, aboriginal peoples have been just as likely as European nationalists to use organic metaphors and single narratives of evolutionary cultural development, although, obviously, with different ideological resonance. See, e.g., the account of the Five Nations Confederacy in Canada: "The meaning of planting this 
However, it has been argued that by asserting cultural authority through traditional teleological and evolutionary models, literary historians risk replicating an ideology they seek to challenge in terms of their identity politics. ${ }^{20}$ They may even end up reasserting "essentialist notions of culture and history; conservative notions of territorial and linguistic propriety, and the 'otherness' ensuing from them." ${ }^{21}$ These very real risks enjoin us to examine more closely the manifest links between nineteenth-century forms of national cultural authorization and current ones based on the politics of identity.

The issue of the persistence of the teleological narrative (and of the dangers of its longevity) came to my attention a few years ago when I became involved in directing two large-scale literary history projects that have attempted to rethink the models used to map forms of cultural authority. Whereas the literary past has been recounted most frequently through the categories of nation (The Literary History of Canada) and language (French literary history), these two projects have worked comparatively and thus outside such boundaries. ${ }^{22}$ They have done so in recognition of the cultural and literary realities of

Great Tree is the Great Peace, and Good Tidings of Peace and Power, and the Nations of the earth shall see it and shall accept and follow the Root and shall arrive here at this Tree and when they arrive here you [the Five Nations] shall receive them and shall seat them in the midst of your Confederacy, and the meaning of placing an Eagle on the top of the Great Tall Tree is to watch the Roots. . . This bundle of arrows signifies that all the Lords and all the Warriors and all the Women of the Confederacy have become united as one person. . . We have now completed our power so that we, the Five Nations Confederacy, shall in the future only have one body, one head and one heart" (Daniel David Moses and Terry Goldie, eds., An Anthology of Canadian Native Literature in English [Toronto: Oxford University Press, 1992], 10).

${ }^{20}$ Jay analyzes Said's position on the postcolonial version of risk as follows: "Ironically, the identity politics of the oppressors became the identity politics of the oppressed, as nationalism was taken up as a primary (and necessary) weapon against imperialism" (20-1).

${ }^{21}$ Rey Chow, Writing Diaspora: Tactics of Intervention in Contemporary Cultural Studies (Bloomington: Indiana University Press, 1993), 17.

22 Carl F. Klinck, gen. ed., Literary History of Canada: Canadian Literature in English, 2d ed., 4 vols. (Toronto: University of Toronto Press, 1976-9o). Denis Hollier, ed., A New History of French Literature (Cambridge, Mass.: Harvard University Press, 1989), is an unconventional history of literature in the French language. 
globalization. Therefore they accept that verbal culture (the broader definition of the literary is intended here) does not develop in isolation within national borders.

One project has been to study all of Latin America, from the inception of the aboriginal cultures through the European conquests and up to the present, according to a model, developed with the help of cultural geographers, that allows the movement of culture to be mapped across borders. ${ }^{23}$ The other project focuses on an area of the world whose cultural and political past has always been told as a history of shifting and conflicting nationalisms: eastern and central Europe. Moving almost counterintuitively away from the concept of nations and nationalisms, this project examines cultural "nodes" or spots at which different cultures have met and merged. Sometimes these nodes are cities whose nationalities have changed through war (e.g., Gdansk/Danzig); sometimes they are people (e.g., Kafka, a Jew writing in German in Prague); sometimes they are geographic forces (e.g., the Danube, which has made possible the material flow of culture and thus interactions among different cultures). The study's theoretical focus is broadly postcolonial, as its contributors explore the traces left by three empires over two centuries. Both projects have been designed to shift the emphasis of literary production and reception away from the nation-state and therefore away from the usual national historical models. ${ }^{24}$ Like the recent Columbia Literary History of the United States and the Cambridge History of American Literature, although within an even wider comparative frame of reference, they seek a more nuanced way to address the new developments in both historiography and the discipline (and politics) of literary studies. ${ }^{25}$

${ }^{23}$ This three-volume project is scheduled to be published by Oxford University Press in 2000. For an outline of the theoretical background see Djelal Kadir, Linda Hutcheon, and Mario J. Valdés, "Collaborative Historiography: A Comparative Literary History of Latin America," American Council of Learned Societies Occasional Paper, 1996.

${ }^{24}$ For an overview of both projects see Linda Hutcheon and Mario J. Valdés, "Rethinking Literary History-Comparatively," American Council of Learned Societies Occasional Paper, 1995 .

${ }^{25}$ Emory Elliott, gen. ed., Columbia Literary History of the United States (New York: Columbia University Press, 1988); Sacvan Bercovitch, gen. ed., Cambridge History of American Literature (Cambridge: Cambridge University Press, 1994-). Elliott once 
While helping develop these alternative models of literary history and working under the influence of current theoretical and historical thinking, ${ }^{26}$ I became aware that the older teleological model had by no means disappeared, despite claims that it should have, that it was no longer sustainable. Stephen Greenblatt, for example, argues that it is intellectually and ideologically bankrupt. ${ }^{27}$ Why, he asks, do we assume that there is only one "immutable narrative of emergence"? Why should we "welcome the renewed imposition ... of an ideology that we have just begun to dismantle?" Perhaps the answer lies in the problematic nature of the first-person plural pronoun used here. Yes, postmodern and poststructuralist theory has "begun to dismantle" the ide-

voiced his concern that the Columbia Literary History should "incorporate recent developments in scholarship and canon reassessment in order to create a book that will fairly represent the diversity of the literature and the variety of current critical opinion" ("The Politics of Literary History," American Literature 59 [1987]: 269). Bercovitch has listed the shared convictions of his collaborators about what constitutes the "problematics" of literary history today: "that race, class, and gender are formal principles of art and therefore integral to textual analysis; that language has the capacity to break free of social restrictions and through its own dynamics to undermine the power structures it seems to reflect; that political norms are inscribed in aesthetic judgment and therefore inherent in the process of interpretation; that aesthetic structures shape the way we understand history, so that tropes and narrative devices may be said to use historians to enforce certain views of the past; that the task of literary historians is not just to show how art transcends culture, but also to identify and explore the ideological limits of their time, and then to bring these to bear upon literary analysis in such a way as to make use of the categories of culture, rather than being used by them" (preface to Reconstructing American Literary History, ed. Sacvan Bercovitch [Cambridge, Mass.: Harvard University Press, 1986], viii).

${ }^{26}$ E.g., James Clifford's examination of the organicist assumptions beneath the anthropological notion of culture ("Cultural systems hold together; and they change more or less continuously, anchored primarily by language and place") and his speculation that the time may have come to replace it with a Foucauldian vision of "powerful discursive formations globally and strategically deployed. Such entities would at least no longer be closely tied to notions of organic unity, traditional continuity, and the enduring grounds of language and locale" ("On Orientalism," in The Predicament of Culture: Twentieth-Century Ethnography, Literature, and Art [Cambridge, Mass.: Harvard University Press, 1988], 273, 274).

${ }^{27}$ These terms come from Greenblatt's response to a preliminary version of the present essay at the Modern Language Association convention in Toronto, December 1997. The subsequent comments are also from Greenblatt's presentation, "Response to Linda Hutcheon." 
ology that subtends teleological narratives, but the history of critical theory proves that not all constituencies have welcomed this dismantling. ${ }^{28}$ The timing, again, has not been fortuitous for minoritized groups whose narratives of emergence may not be fully established and articulated. Dismantling, it has been argued, is the luxury of the already established and the already articulated. Nevertheless, the stubborn persistence of the (national) developmental model of literary history requires further investigation, if only because of the clear ideological risks inherent in adopting its implicit historical assumptions of cultural authorization.

One way to start such investigation would be to examine how cultural nationalisms have done their nation-building work. Their chosen evolutionary narratives of literary history have directly contributed, by their very structures, to the defining of what Lauren Berlant (in another context) calls the "National Symbolic," through which "the historical nation aspires to achieve the inevitability of the status of natural law." But, as we daily witness, nations are not natural. They are constructed and maintained by communal consent; they fall apart when it is refused. Raymond Williams argues that the idea of nation is tied to " "placeable' bonding": "We are born into relationships, which are typically settled in a place." Nevertheless, it is clear that we also actively acquire a sense of national identity through a shared heritage of cultural, political, and social values to which we must assent. ${ }^{29}$ This element of conscious agency prevents me (in all good conscience) from making the kind of separation that some are happy to make between, on the one hand, the romantic concern for the noble ideal of national-

${ }^{28}$ See, e.g., Barbara Christian, "The Race for Theory," Feminist Studies 14 (1988): $67-79$, esp. $7^{1-2 .}$

${ }^{29}$ Berlant, The Anatomy of National Fantasy: Hawthorne, Utopia, and Everyday Life (Chicago: University of Chicago Press, 1991), 20; Williams, "The Culture of Nations," in Towards 2000 (London: Hogarth, 1983), 180. For Edward Hallett Carr, nations are neither universal nor natural but are instead constructed entities "confined to certain periods of history and to certain parts of the world" (Nationalism and After [London: Macmillan, 1945], 39). In fact, as Jean Franco argues, the concept of nation fails to provide "systems of meaning and belief" for writers in Latin America today ("The Nation as Imagined Community," in The New Historicism, ed. H. Aram Veeser [New York: Routledge, 1989], 208). 
ity and, on the other, the modern fanaticism of nationalism (e.g., Steiner, 82). I find this evaluative distinction problematic, not to say nostalgic, and much too easy, even if I am quite willing to accept that nationalism (or at least national self-awareness) need not entail jingoistic, aggressive self-aggrandizement. Unfortunately - and sometimes spectacularly-it often does.

As Michael Ignatieff succinctly puts it in describing our current world, "The repressed has returned, and its name is nationalism." Paul Valéry named it simply "history" but saw it as equally frightening: "History is the most dangerous product evolved from the chemistry of the intellect. ... It causes dreams, it intoxicates whole peoples, gives them false memories, quickens their reflexes, keeps their old wounds open, torments them in their repose, leads them into delusions either of grandeur or persecution, and makes nations bitter, arrogant, insufferable, and vain." 30 When we speak of nationalism, however, we are dealing not only with a potentially dangerous political power but also with a cultural force whose institutionalized results (and causes) represent and constitute an important sense of both belonging and recognition for a people. ${ }^{31}$ Whether ethnically based or not, this nationalism is explicitly cultural, and it often becomes the job of cultural industries, including literary histories, to establish and define the pure and originary (or primordial) culture and to demonstrate its continuities through to the present and into the future. ${ }^{32}$

In his famous 1882 lecture "What Is a Nation?" Ernest Renan denounced the defining of nation in terms of the "ethnographic prin-

30 Ignatieff, Blood and Belonging: Journeys into the New Nationalism (Harmondsworth: Penguin, 1993), 5; Valéry, "On History" (1931), in History and Politics, trans. Denise Folliot and Jackson Mathews, vol. 10 of The Collected Works of Paul Valéry, ed. Jackson Mathews (New York: Bollingen Foundation, 1962), 114.

${ }^{31}$ Charles Taylor argues that the need for recognition fuels identity politics as much as it does nationalism and that to withhold recognition can be a form of oppression ("The Politics of Recognition," in Multiculturalism: Examining the Politics of Recognition, ed. Amy Gutmann [Princeton, N.J.: Princeton University Press, 1994], $3^{6)}$.

32 Nostalgic "primordialism" is often accepted as constructed (i.e., not natural), especially by theorists for whom nations are "imagined communities" (to use Anderson's influential phrase). But such an acknowledgment of constructedness does not stop ethnic nationalisms from being powerful today - in very concrete terms, as we know too well. See also E. J. Hobsbawm, Nations and Nationalism since 1780: Programme, Myth, Reality (Cambridge: Cambridge University Press, 1990), 91. 
ciple" on the grounds that European nations were all essentially of mixed blood and that the "primordial right of races is as narrow and as perilous for genuine progress as the national principle is just and legitimate." Writing even before the major diasporic migrations of the twentieth century, Renan rejected the related nationalist claims of language, religion, and geography along with that of race. He then defined the nation in both historical and consensual terms, as combining the common possession of "a rich legacy of memories" with "the desire to live together, the will to perpetuate the value of the heritage that one has received." 33 Yet the very desire to perpetuate a separate cultural heritage (and thus identity) is behind the nationalist urge (witnessed in the former Soviet Union and Yugoslavia) to carve large multiethnic states into more ethnically homogeneous units. In recent years ethnic nationalisms have certainly proliferated, paradoxically in the face of globalization's implicit demystification of the ideology of national culture and its emphasis on international and intercultural relationships. Frederick Buell suggests that nationalism and globalism coexist today without canceling one another out. This condition can be seen in literary-historical terms, for instance, in the fact that "globally disseminated literary forms and influences are used, usually covertly, in the evocation or recreation of endangered traditions and cultures" (63).

As a quick glance back at the German romantics illustrates, these new nations are not alone in resorting to "the idiom of antiquity, tradition, cultural authenticity, linguistic uniqueness, ethnicity, and territorial integrity." ${ }^{44}$ In their formative moments, it would seem, nations have always made (and often remade) their histories, both literary and political. They have often exaggerated their antiquity - that is, often concealed their newness. ${ }^{35}$ The "imagined community" of the nation is

${ }^{33}$ Renan, "What Is a Nation?" (1882), in Bhabha, Nation and Narration, 13, 19.

${ }^{34}$ Rob Nixon, "Of Balkans and Bantustans: Ethnic Cleansing and the Crisis in National Legitimation," in Dangerous Liaisons: Gender, Nation, and Postcolonial Perspectives, ed. Anne McClintock, Aamir Mufti, and Ella Shohat (Minneapolis: University of Minnesota Press, 1997), $8_{5}$.

35 "The past is always altered for motives that reflect present needs. . . Rendered grand or homely, magnified or tarnished, history is continually altered in our private interests or on behalf of our community or country" (Lowenthal, 348; see also 336$)$. 
frequently based as much on shared forgetting as on shared nostalgic memory. ${ }^{36}$

Adapting such a legitimating national(ist) model to the different (if related) ends of identity politics is not without serious dangers. The most obvious involves the basic decision of how a group defines itself. How does it determine its boundaries? For determine them it must. To establish its identity, a group must be inclusive (to assert community) but also exclusive (to assert its difference from others), and therein lies the problem. Henry Louis Gates Jr. puts the dilemma in these terms:

If a nationality comes into its own through the production of literature, the apparatus of recognition - the 'selection of classics' to which E. R. Curtius tells us canon formation must proceed-remains integral to its realization. Inevitably, the process of constructing a group identity, at the margins as at the very center, involves active exclusion and repudiation; self-identity requires the homogeneity of the self-identical. Ironically, then, the cultural mechanism of minority self-construction must replicate the mechanism responsible for rendering it marginal in the first place. ${ }^{37}$

In other words, there is a tension between a minoritized group's desire to "make the continuum of history explode" (to use Walter Benjamin's powerful phrase) and an equally important need to set up and police borders that might mimic the silencing or stigmatizing mechanisms of that very "continuum." ${ }^{8}$ Identity building through boundary drawing is obviously deterritorialized in the case of the politics of identity, but the "tendency to inner cultural homogeneity and outer cultural separatedness" is a property that the politics of identity shares with territorially based nation-states. ${ }^{39}$ While many groups may indeed refuse to define themselves in terms of a basic core, others have strategically

${ }^{36}$ See Svetlana Boym, "From the Russian Soul to Post-Communist Nostalgia," Representations 49 (1995): 134. On how people make meaning of their past through forgetting see also Gertrude Himmelfarb, The New History and the Old (Cambridge, Mass.: Belknap Press of Harvard University Press, 1987), 130.

${ }^{37}$ Gates, "Ethnic and Minority' Studies," in Introduction to Scholarship in Modern Languages and Literatures, ed. Joseph Gibaldi, 2d ed. (New York: Modern Language Association of America, 1992), 295-6.

38 Benjamin, "Theses on the Philosophy of History," in Illuminations, ed. Hannah Arendt, trans. Harry Zohn (New York: Schocken, 1969), 261.

${ }^{39}$ Zygmund Bauman, "Soil, Blood, and Identity," Sociological Review 4o (1992): 693. 
invoked some kind of essentialism precisely to draw including and excluding boundaries. ${ }^{40}$ Smaro Kamboureli, who attacks such essentializing in her analysis of the construction of ethnicity in anthologies of Canadian ethnic-minority writing, argues that ethnicity risks becoming "a master narrative of marginalization that subordinates the subject's present condition to its past roots, which are privileged because of their 'authenticity." But Paul Gilroy points out that in its important construction of culturally homogeneous "communities of sentiment," black cultural nationalism often relies on "ethnic absolutism" to create a strong sense of social belonging. ${ }^{41}$

Women have done the same thing, according to some feminist literary historians. Margaret J. M. Ezell suggests that even self-conscious and self-critical feminist literary historians might well want to argueagain, for interventionist reasons related to community defining - that there is a tradition of women's writing and that it can best be told as an evolutionary narrative of progress. In her study of feminist literary histories and anthologies, however, Ezell notes the costs of this complicity: "By consciously permitting our perceptions of the past to be shaped by unexamined ideologies, perhaps unwittingly carried over from certain privileged texts or theories, we may have infused the values and standards of those texts and theories in our constructions of the past. The result could be that we have unintentionally marginalized or devalued a significant portion of female literary experience." Thus "certain female experiences are not considered as valuable in constructing a tradition as others. In the evolutionary narrative of women's literary history, structured on a 'great woman' or 'turning point' linear model, we have labeled winners and losers; the 'best' examples of women's writing." 42 Yet in their use of a developmental narrative model these feminist historians - like some gay, lesbian, or queer historiansreveal the need to recover and document a cultural heritage, as well as

${ }^{40}$ For a fuller discussion of essentialism see Diana Fuss, Essentially Speaking: Feminism, Nature, and Difference (New York: Routledge, 1989).

${ }^{41}$ Kamboureli, "Canadian Ethnic Anthologies: Representations of Ethnicity," Ariel 25, no. 4 (1994): 28; Gilroy, "There Ain't No Black in the Union Jack": The Cultural Politics of Race and Nation (Chicago: University of Chicago Press, 1991), 60.

42 Ezell, Writing Women's Literary History (Baltimore, Md.: Johns Hopkins University Press, 1993), 7, 61. Others, like Lawrence Buell, claim that feminist revisions of the canon (as opposed to rejections of canon formation altogether) could be seen as a "conservative hankering to restabilize" ("Literary History without Sexism? Feminist 
to contribute to it and its future. Through the very structure of this kind of literary history they can embody the progressivist intentions of their agendas. Their scholarly work is designed to identify, reevaluate, and then institutionalize a usable past-usable, that is, for the future, for interventionist rather than purely conservationist (or, for that matter, conservative) purposes.

If the historical narratives of some of today's minoritized literatures do look similar to nineteenth-century narratives of nationhood, therefore, it may be because the respective groups' political as well as scholarly needs are not so very different. ${ }^{43}$ In other words, marginalized groups may be driven not by reactionary nostalgia as much as by canny political pragmatism. This kind of narrative worked once-for nationsand it just might work again: such is the manifest utopian power of evolutionary narratives of progress. This choice is clearly being made in spite of all the dangers of complicity (against which, however, all groups must constantly be on the alert).

Many interventionist narratives are teleological and less nostalgic than utopian because their politics are goal-driven: they discuss the past, but they aim toward progress and emancipation. And the bedrock narrative of development that historically guarantees a sense of cultural legitimacy has to be laid down before competing, correcting, even counterdiscursive narratives can be articulated. Without that bedrock, would we ever have had Gates's rejection of the "transcendent presence" of blackness and, in its stead, his promoting of the metaphor of African American "signifying" as the way to describe that particular literary history? Would we have had Michael Chapman's plural and complex account of the oral and written cultures of different races and their interethnic collaborations and distinctions in southern Africa? ${ }^{44}$ It may well be true, as Peter Brooker suggests, that

Studies and Canonical Reconception," American Literature 59 [1987]: 103, referring to Annette Kolodny, "The Integrity of Memory: Creating a New Literary History of the United States," American Literature 57 [1985]: 291-307).

${ }^{43}$ For a different interpretation of the combination of "independence and complicitous intertwining" of national canons with the "transnational textuality" represented by the writing of women, gays and lesbians, aboriginals, and so on, see Frank Davey, Canadian Literary Power (Edmonton, Alta.: NeWest, 1994), 76.

${ }^{44}$ Gates, "The Signifying Monkey," in Black Literature and Literary Theory, ed. 
Enlightenment principles enjoy "continuing vitality" in "politically engaged cultures of marginalized groups," but the same groups have generally been alert to the exclusions and entrapments as well as to the emancipatory potential of those principles, especially in their literary-historical manifestations. ${ }^{45}$ The longevity and continuing appeal of the developmental model (and its ideological underpinnings), therefore, have to be understood - in context-and not condemned outright as signs of backsliding. What Gilroy calls the "tragic popularity of ideas about the integrity and purity of cultures" (and about how that purity is historically legitimated) needs to be contextualized and historicized, in full view of its very real dangers. ${ }^{46}$

The stubborn persistence of an evolutionary national model in current (self-critical) literary-historical thought is therefore not necessarily a worrisome sign of either retrogressive nostalgia or, in an age of theoretical self-reflexivity, political naiveté about the ideology of historiography. From the point of view of newly decolonized nations or marginalized groups, such a model may have real practical advantages. Of course, many of their literary historians have engaged head-on the problems of writing literary history at the end of the twentieth century, when electronic technology has changed the kinds of scholarship that are even possible; when the "literary" has been redefined to include many different categories of verbal discourse, including the popular (with concomitant changes in concepts of canonicity); and, most relevant here, when challenges to the epistemological status of historiography have undermined confidence in the institution of literary history itself. Instead, their open-eyed decision at times to retain the developmental model of evolution can be interpreted as a strategic, pragmatic acknowledgment of, first, the shared interventionist drive at the heart of both emerging nations' politics in any century and the politics of identity today and, second, the ongoing validating structures and continuing ideological power that utopian narratives of progress possess in the struggle to articulate a usable past.

Henry Louis Gates Jr. (New York: Methuen, 1984), 315; Chapman, Southern African Literatures (London: Longman, 1996).

${ }^{45}$ Brooker, New York Fictions: Modernity, Postmodernism, the New Modern (New York: Longman, 1995), 133.

${ }^{46}$ Gilroy, The Black Atlantic: Modernity and Double Consciousness (Cambridge, Mass.: Harvard University Press, 1993), 7. 